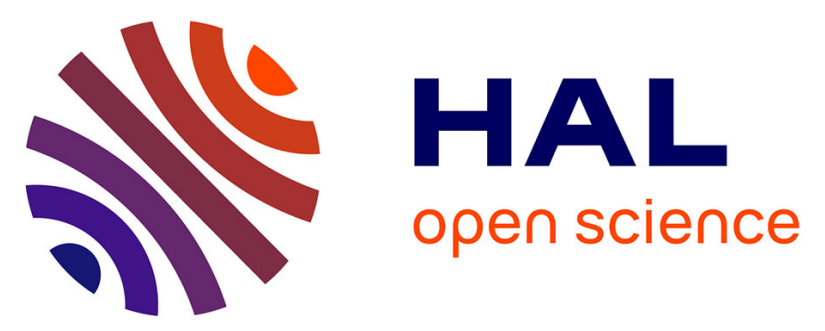

\title{
Performance characteristics of the VIDAS® ANTI-HEV IgM and IgG assays
}

Florence Abravanel, Nadège Goutagny, Raphaelle Joffray, Emile Eichenlaub, Sylviane Baron, Alexandre Aversenq, Sandrine Bourg, Laurence Mercier, Audrey Larue Triolet, Didier Poirault, et al.

\section{To cite this version:}

Florence Abravanel, Nadège Goutagny, Raphaelle Joffray, Emile Eichenlaub, Sylviane Baron, et al.. Performance characteristics of the VIDAS® ANTI-HEV IgM and IgG assays. Journal of Clinical Virology, 2019, 112, pp.10 - 14. 10.1016/j.jcv.2019.01.005 . hal-03485675

\section{HAL Id: hal-03485675 \\ https://hal.science/hal-03485675}

Submitted on 20 Dec 2021

HAL is a multi-disciplinary open access archive for the deposit and dissemination of scientific research documents, whether they are published or not. The documents may come from teaching and research institutions in France or abroad, or from public or private research centers.
L'archive ouverte pluridisciplinaire HAL, est destinée au dépôt et à la diffusion de documents scientifiques de niveau recherche, publiés ou non, émanant des établissements d'enseignement et de recherche français ou étrangers, des laboratoires publics ou privés.

\section{(ㅇ)(1) $\$$}

Distributed under a Creative Commons Attribution - NonCommerciall 4.0 International 
3 Florence Abravanel ${ }^{1,2^{*}}$, Nadège Goutagny ${ }^{3 *}$, Raphaelle Joffray ${ }^{1}$, Emile Eichenlaub ${ }^{3}$, Sylviane

4 Baron $^{1}$, Alexandre Aversenq ${ }^{1}$, Sandrine Bourg ${ }^{3}$, Laurence Mercier ${ }^{3}$, Audrey Larue Triolet ${ }^{3}$,

5 Didier Poirault ${ }^{3}$, Marissa Loubet ${ }^{3}$, Soizic Daniel ${ }^{3}$, Francoise Luciani $^{3}$, Catherine Pothion ${ }^{3}$,

6 Carole Tourneur ${ }^{3}$, Jean-Marc Dugua ${ }^{3}$, Sébastien Lhomme ${ }^{1,2}$ and Jacques Izopet ${ }^{1,2}$

${ }^{1}$ CHU Toulouse, Hôpital Purpan, Laboratoire de virologie, National Reference Center for

Hepatitis E, F-31300 France

2 INSERM, U1043, Centre de Physiopathologie de Toulouse Purpan, Toulouse, F-31300

France

${ }^{3}$ Biomérieux SA, Chemin de l'Orme, Marcy l'étoile, France

* These authors contributed equally to this work.

Abstract Word count: 235 words $(<250)$

Text word count: 2390 words $(<2500)$

Corresponding author:

Florence Abravanel

Laboratoire de virologie, Inserm U1043

CHU Toulouse Purpan, 31059 Toulouse cedex

France

Tel: (33) 567690424

Fax: (33) 567690425

Email: abravanel.f@chu-toulouse.fr 
Background. Several unautomated anti-HEV diagnostic tests are presently available.

Objective. We have evaluated the performance of the new automated VIDAS ${ }^{\circledR}$ ANTI-HEV $\lg M$ and IgG assays.

Study design. We assessed the reproducibility and cross-reactivity of both VIDAS assays and the analytical sensitivity and linearity of the VIDAS IgG assay. We also tested the VIDAS and comparator assays Wantai IgG and IgM on immunocompetent and immunocompromised patients. Data were analysed according to the infectious profile, with samples from viremic phase (HEV RNA/IgM positive) and post-viremic phase (HEV RNA negative, IgM positive) infections, and uninfected patients (HEV RNA/IgM negative).

Results. Within-run reproducibility was $<10 \%$ and between-run reproducibility was $<12 \%$ for both assays. We found no cross-reactivity, except for the VIDAS IgG assay in some patients with HBV $(1 / 10)$ or malaria (3/23) infections and for the VIDAS IgM assay in some HIVinfected patients (1/10). The VIDAS IgG assay was linear over 0.10-10.0 U/mL. Analytical sensitivity of the IgG assay was $0.71 \mathrm{IU} / \mathrm{ml}$ (probit analysis). The clinical sensitivity of the VIDAS IgM assay was $97.65 \%$ for viremic samples (83/85) and $59.15 \%(42 / 71)$ for postviremic samples from immunocompetent patients. It was $78.95 \%(45 / 57)$ for acute phase samples and $77.78 \%(28 / 36)$ for post-viremic samples from immunocompromised patients. Specificity was excellent (>99\%) in both populations.

Conclusion. The analytical and clinical performance of the new VIDAS ${ }^{\circledR}$ ANTI-HEV assays was excellent. These rapid, automated assays for detecting HEV antibodies will strengthen the arsenal for diagnosing HEV infections. 


\section{Background.}

Hepatitis E virus (HEV) is a leading cause of viral hepatitis worldwide (1). Five major genotypes within the Orthohepevirus $A$ species, Hepeviridae family, are known to infect humans (genotypes 1-4 and 7) (2). Genotypes 1 and 2 are restricted to humans and are predominant in developing countries, where the virus is transmitted through faecally contaminated drinking water. HEV genotypes 3 and 4 are predominant in industrialised countries where zoonotic transmission occurs (2).

Hepatitis E virus typically causes an acute, self-limiting illness similar to other viral hepatitis (3). Chronic cases of hepatitis E caused by infections with HEV genotypes 3, 4 and 7 have been reported in immunocompromised individuals, such as organ transplant recipients (4-6), patients with haematological malignancies $(7,8)$ and individuals infected with HIV $(9$, 10).

HEV infections are diagnosed by laboratory testing since their clinical presentation does not differ from that of other pathogens causing hepatitis (11). A combination of serology (IgM and IgG tests) and nucleic acid assays is used (12). The brief window in which HEV RNA can be detected in the serum or faeces of immunocompetent individuals is confined to the acute phase of the disease. Several commercial serological HEV diagnostic tests are currently available, but their sensitivities and specificities vary widely (13-18). One recent evaluation of anti-HEV assays found that their IgM assay results agreed for only $71 \%$ of suspected hepatitis E patients while the IgG assays agreed for only $70 \%$. Their sensitivity also varied (42-96\%), which was reflected in the detection limits: up to 19-fold variations for IgM and 17-fold for IgG (13). And none was automated. 


\section{Objectives}

To evaluate the analytical and clinical performances of the new VIDAS ${ }^{\circledR}$ ANTI-HEV IgM and IgG assays by testing samples from immunocompetent and immunocompromised patients.

\section{Study design}

\subsection{Quality control materials and clinical samples}

The reproducibility of the two VIDAS ${ }^{\circledR}$ ANTI-HEV assays was determined using serum samples according to the Clinical and Laboratory Standards Institute guidelines (CLSI) EP5-A3 guideline. Samples (3-4) covering the assay range were tested using 2 reagent lots in duplicate, twice a day for 10 days, on 3 different VIDAS $^{\circledR}$ instruments.

We assessed the cross-reactivity of the VIDAS $^{\circledR}$ ANTI-HEV assays by testing samples positive for IgM or IgG HAV, HBV, HCV, CMV, EBV, HIV, dengue or malaria infection. All these samples tested negative for HEV IgG and IgM with the Wantai assays (Biologic Pharmacy Enterprise, China).

The linearity of the VIDAS $^{\circledR}$ ANTI-HEV IgG assay was evaluated according CLSI EP6-A guidelines, using two pools of serum, one with a high and one with a low concentration of HEV IgG (near the limits of the VIDAS ${ }^{\circledR}$ assay range). High and low samples were sequentially mixed to generate 8 samples of intermediate concentrations. Each sample was tested in triplicate with 2 reagent lots.

The analytical sensitivity of both the VIDAS and Wantai HEV IgG assays was assessed by testing 20 replicates of each HEV IgG concentration $(0.15-0.7 \mathrm{U} / \mathrm{mL}, 0.05 \mathrm{U} / \mathrm{mL}$ intervals) 
prepared by diluting the WHO anti-HEV standard (NIBSC 95/584) in PBS containing 7.5\%

bovine serum albumin.

The VIDAS $^{\circledast}$ ANTI-HEV IgM and ANTI-HEV IgG clinical trial was a prospective monocentric study. We tested 659 samples from immunocompetent and immunocompromised patients (mean age: 49 years; range 1-91 years; male/female ratio: 1.01) characterized for hepatitis E (HEV RNA detection and Wantai HEV IgM assay). Data were analysed with reference to the infectious profile, with samples from the viremic phase (WantaiHEV IgM and HEV RNA positive; $n=142$ ), post-viremic phase (Wantai IgM positive, HEV RNA negative; $n=107$ ) and uninfected (HEV RNA negative and Wantai HEV IgM negative; $\mathrm{n}=410$ ). The samples were collected between September 2016 and June 2017 during hospitalization and routine out-patient visits. Serum or EDTA-plasma samples were collected prospectively: $86.8 \%$ were stored at $-20{ }^{\circ} \mathrm{C}$ and $13.2 \%$ were tested fresh.

We also tested patients infected with HEV genotype $1(n=2)$, genotype 3-rabbit $(n=2)$ and genotype $4(n=2)$.

\subsection{Laboratory Investigations}

The VIDAS $^{\circledR}$ ANTI-HEV IgM and IgG assays (BioMérieux, France) used $100 \mu \mathrm{l}$ of samples (blood plasma or serum). Both these sandwich enzyme immunoassays were coated with genotype 1 antigens. The VIDAS ${ }^{\circledR}$ ANTI-HEV IgM is a qualitative assay, the test value is automatically calculated by the instrument as an index value. Results were considered to be negative if their IgM index value was below the threshold value (set at 1.00). 

which is proportional to the concentration of HEV IgG in the sample. Test values are

117 automatically calculated by the instrument and expressed in $\mathrm{U} / \mathrm{mL}$. The VIDAS $^{\circledR}$ ANTI-HEV $^{-}$

118 IgG assay has been standardized to internal reference calibrators titrated against the WHO

119 international standard NIBSC 95/584. Results were considered to be negative if the IgG was 120 below the threshold value $(0.56 \mathrm{U} / \mathrm{mL})$.

The Wantai HEV IgG and IgM EIA kits (Wantai Biologic Pharmacy Enterprise, Beijing, China) were used according to the manufacturer's instructions. HEV RNA was tested using an accredited ISO15189 RT-PCR assay (19).

\subsection{Statistical analysis.}

126 Variability is expressed as the standard deviation (SD) or the coefficient of variation (CV).

127 Linearity was evaluated as described in the CLSI protocol EP6-A with an accepted deviation 128 from linearity $\leq+/-12 \%$ over the entire measuring range. Probit analysis of data from serial 129 dilutions of the WHO standard was used to determine the analytical sensitivity of the HEV 130 IgG assays. 


\section{Results}

\subsection{Analytical performances of the VIDAS ${ }^{\circledR}$ HEV assays}

Reproducibility. Within-run reproducibility was defined as the precision within-lot, withinrun and within-instrument. Between-run reproducibility included all variable factors: run, day, and lot. The within-run reproducibility of the VIDAS $^{\circledR}$ ANTI-HEV IgM assay yielded a CV of $4.1-9.9 \%$. Between-run reproducibility gave a CV of $7.4-13.0 \%$ (Table 1). The within-run reproducibility of the VIDAS $^{\circledR}$ IgG assay gave a CV of $4.5-7.8 \%$ and the between-run reproducibility gave a CV of 9.1 - $11.9 \%$ (Table 1).

Cross-reactivity. The cross-reactivity of the VIDAS $^{\circledR}$ assays evaluated the potential interference from other infections found in similar areas. All the samples tested negative for HEV IgG and IgM with the Wantai assays. None cross-reacted in the VIDAS $^{\circledR}$ IgM assay except 1/10 HIV-positive sample. Similarly, very few cross-reacted in the VIDAS $^{\circledR}$ IgG assay: 1/10 HBV-positive sample and 3/23 malaria samples (Table 2).

Linearity of the VIDAS $^{\circledR}$ ANTI-HEV IgG. Samples $(n=8)$ were prepared by diluting the high-HEV IgG sample with the low-concentration sample. A weighted linear regression between observed and expected concentrations was linear from 0.10 to $10.0 \mathrm{U} / \mathrm{mL}$ with $<10 \%$ deviation from linearity (Figure 1). The slope of the regression line was $1.0199\left(R^{2}=0.99\right)$.

Analytical sensitivity of the HEV IgG assays. Probit analyses of the replicates of the diluted WHO standard gave an analytical sensitivity of $0.71 \mathrm{U} / \mathrm{ml}[95 \% \mathrm{Cl}: 0.69-0.75]$ for the VIDAS ${ }^{\circledR}$ IgG assay and $0.27 \mathrm{U} / \mathrm{ml}[95 \% \mathrm{Cl}: 0.24-0.33]$ for the Wantai IgG assay.

\subsection{Clinical Performances of the VIDAS ${ }^{\circledR}$ ANTI-HEV IgM assay.}


Sensitivity and specificity of the VIDAS ${ }^{\circledR}$ ANTI-HEV IgM in immunocompetent patients. Of the 85 acute phase samples (viremic samples), 83 tested positive with the VIDAS $^{\circledR} \operatorname{lgM}$ (sensitivity: 97.65\%; 95\%Cl: 91.76 - 99.71\%). The 71 Wantai IgM-positive HEV RNA-negative samples (post-viremic) included 42 positive and 29 negative (sensitivity: 59.15\%; 95\%Cl: $47.54-69.83 \%)$. These 29 samples that tested negative with the VIDAS $^{\circledR} \operatorname{IgM}$ assay included 25 that were positive with the VIDAS ANTI-HEV IgG assay. Only 2 of the 303 negative samples tested positive with the VIDAS IgM (specificity: 99.34\%; 95\%Cl: 97.64 - 99.92\%).

Sensitivity and specificity of the VIDAS ${ }^{\circledR}$ ANTI-HEV IgM in immunocompromised patients. The 57 acute phase samples included 45 that tested positive with the VIDAS $^{\circledR}$ IgM assay (sensitivity: 78.95\%; 95\%Cl: 66.71 - 87.53\%). The 36 Wantai IgM-positive/HEV RNA-negative samples included 28 that tested positive and 8 that tested negative (sensitivity: 77.78; 95\% Cl: $61.92-88.28 \%$ ). These 8 VIDAS $^{\circledR}$ IgM assay-negative samples included 5 that were VIDAS IgG-positive. The 107 negative samples included one that was VIDAS IgM-positive (specificity: 99.07\%; 95\%Cl: 94.90 - 99.98\%).

\subsection{Clinical Performance of VIDAS ${ }^{\circledR}$ ANTI-HEV IgG assay.}

Sensitivity and specificity of the VIDAS ${ }^{\circledR}$ ANTI-HEV IgG in immunocompetent patients. The 85 viremic samples included 81 that tested positive with the VIDAS IgG (sensitivity: 95.29\%; 95\% Cl: $88.39-98.70 \%)$. Three of the 4 negative VIDAS IgG samples were also negative with the Wantai IgG assay. Similarly, 65 of the 71 post-viremic samples tested positive and 6 tested negative (sensitivity: 91.55\%; 95\%Cl: $82.76-96.07 \%$ ). Three of these 6 negative samples also tested negative with the Wantai IgG assay. The 303 negative samples included 10 that tested positive with the VIDAS IgG (specificity: $96.70 \%$; $95 \% \mathrm{Cl}$ : $94.01-98.41 \%$ ). 
177 Three of these 10 samples that were positive with the VIDAS $^{\circledR} \operatorname{IgG}$ assay were also positive

178 with the Wantai IgG assay.

Sensitivity and specificity of the VIDAS ${ }^{\circledR}$ ANTI-HEV IgG in immunocompromised patients. The 57 viremic phase samples included 38 that tested positive with the VIDAS ANTI-HEV IgG (sensitivity: $66.67 \%$; $95 \% \mathrm{Cl}: 53.72-77.51 \%$ ). The 36 post-viremic samples included 32 that tested positive and 4 that tested negative (sensitivity: $88.89 \%$; $95 \% \mathrm{Cl}: 74.69-95.59 \%)$. The 107 negative samples included 4 that tested positive with the VIDAS IgG (specificity: 96.26\%; $95 \% \mathrm{Cl}: 90.70-98.97 \%)$.

\subsection{HEV antibodies detection in HEV genotype 1, 3-rabbit and 4 infections}

All the samples from patients with HEV genotype 1, 3-rabbit and 4 infections were positive for HEV IgG and IgM using both the Wantai and VIDAS ${ }^{\circledR}$ assays.

\section{Discussion}

Our evaluation of HEV IgM and HEV IgG assays developed for the VIDAS $^{\circledR}$ system in immunocompetent and immunocompromised patients indicated that they were very sensitive for samples collected at the viremic phase of infection and extremely specific.

Several serological anti-HEV diagnostic tests have been evaluated recently. Their sensitivities seem to vary widely, which has complicated data interpretation $(13,15,17,20$, 21). The present clinical evaluation of the $\operatorname{VIDAS}^{\circledR} \lg M$ assay indicates that it is very sensitive (97.65\%) in acutely infected (HEV RNA positive) immunocompetent patients and less (78.95\%) in immunocompromised patients. These results agree well with those of HEV IgM 
assays evaluated in industrialized countries where genotype 3 is prevalent $(14,15,22,23)$.

The VIDAS IgM assay coated with genotype 1 antigens was equally sensitive for detecting antibodies in genotype 3-infected individuals, consistent with other studies (14, 15, 24, 25). However, the VIDAS IgM assay was less sensitive (only 59.15\%) when tested on Wantai HEV IgM-positive/HEV RNA-negative samples from immunocompetent patients. Thus, the VIDAS IgM assay is less effective than the Wantai assay for detecting low concentrations of HEV $\operatorname{IgM}$. As the concentration of HEV IgM decreases with time and becomes undetectable 4 to 6 months after an acute infection (26), it may become undetectable earlier after an acute infection with the VIDAS assay than with the Wantai. Norder et al. found that the DiaPro assay remained positive for the longest after the onset of an HEV infection (13). Therefore, the cut-off value determined by the manufacturer may also influence the assay sensitivity (15). This restricted ability to detect long-lasting HEV IgM may help in patient management as the clinician can rely on the HEV IgM assay for diagnosing an acute hepatitis E infection. The specificity of the VIDAS IgM assay was also excellent in agreement with the reported specificities of IgM assays $(13,14,22,23)$. Its cross-reactivity with interfering infections was also very limited. Anti-HEV IgM assays may suffer from a high proportion of false-positive reactions due to EBV or CMV infections (27-29), but this was not a feature of the VIDAS ${ }^{\circledR}$ ANTI-HEV IgM assay in our hands.

The analytical sensitivities HEV IgG assays also vary, which strongly influences the seroprevalence rates $(16,21,30,31)$. Evaluations of the analytical sensitivity of HEV IgG assays have found differences: from $0.2 \mathrm{U} / \mathrm{ml}$ (Wantai assay) to $6.31 \mathrm{U} / \mathrm{ml}$ (Mikrogen assay, old version) (13-15). The Wantai IgG analytical sensitivity varies from 0.2 to $0.4 \mathrm{U} / \mathrm{ml}(13-15)$, which is similar to the results found for the Wantai assay in this study. The VIDAS ${ }^{\circledR}$ ANTI-HEV 
IgG assay appears to perform as well as other HEV IgG assays (analytical sensitivity: 0.71 $\mathrm{U} / \mathrm{ml}$ ). The clinical sensitivity of the VIDAS $^{\circledR} \lg$ assay was $95.29 \%$ in immunocompetent patients and $66.67 \%$ in immunocompromised patients, in good agreement with previously reported data for the Wantai IgG assay in HEV RNA positiveve patients: sensitivity $93.2 \%$ in immunocompetent and $45 \%$ in immunocompromised (22). The VIDAS IgG assay is also a quantitative assay that is linear up to $10 \mathrm{U} / \mathrm{ml}$. Only the Euroimmun HEV IgG assay gives quantitative results based on the WHO standard validated by the manufacturer. According to the package insert, the Euroimmun HEV IgG assay is linear up to $25 \mathrm{U} / \mathrm{ml}$, but it has a higher limit of detection $(1.5 \mathrm{U} / \mathrm{ml})(15)$.

The VIDAS IgG assay was also highly specific, with values similar to those reported for other HEV IgG assays $(13,14,20,22)$. It also displayed very limited cross-reactivity with interfering infections, as did VIDAS IgG prototypes (32). It cross-reacted in samples from 3 patients with malaria. However, this diagnosis is rarely performed for patients who have not traveled abroad in European countries.

We also assessed the ability of the VIDAS $^{\circledR}$ assays to detect HEV antibodies in patients infected with genotype 1, genotype 3-rabbit or genotype 4. The few samples tested indicated that both $\operatorname{VIDAS}^{\circledR}$ assays to detected HEV antibodies with the same spectrum as the Wantai assay. Although the anti-HEV assays use genotype 1 antigens, they detected antibodies directed against other genotypes because of the considerable cross-reactivity between the genotypes, which is consistent with HEV having a single serotype (33).

The ANTI-HEV VIDAS ${ }^{\circledR}$ assays can be performed on automated VIDAS ${ }^{\circledR}$ instruments like the mini-VIDAS ${ }^{\circledast}$ or the VIDAS $3^{\circledast}$ automat. This latter immunoanalyzer is a fully automated benchtop immunoassay system with full traceability. Its reduced hands-on time from the sample to the result $(<40 \mathrm{~min})$ enables efficient management of emergency tests. 
Several immunochromatographic rapid tests are available for rapidly detecting HEV IgM (15,

247

248

249

250

251

252

253

254

255

256

257

258

259

260

261

262

23) but they are relatively insensitive ( $90 \%$ in immunocompetent patients) and interpreting the results is sometimes difficult due to very faint bands and great dependence on the operator.

Thus, the $\operatorname{VIDAS}^{\circledR}$ system provides sensitive, specific automated tests that are suitable for the rapid diagnosis of acute hepatitis $E$ and are useful addition to the arsenal for diagnosing HEV infections. The VIDAS ${ }^{\circledR}$ ANTI-HEV IgG assay is a quantitative assay with a low detection limit that is appropriate for determining the HEV status in epidemiological studies.

Competing interests: $F A, R J, A A, S B, S L$, and JI: none. NG, EE, SB, LM, ALT, DP, SD, FL, CP, CT and JMD, are employed by Biomérieux.

Funding. The study was funded by BioMérieux.

Acknowledgments: The English text was checked by Dr Owen Parkes.

Ethical statement. Patient records and information were anonymized and de-identified prior to analysis. Ethical approval was obtained from the French "Comité de Protection des Personnes Nord Ouest I" (N²017-A00196-47). 
1. WHO.

Hepatitis

E. WHO

available

from http://www.who.int/mediacentre/factsheets/fs280/en/. 2014;27(1):116-38.

3. Kamar N, Izopet J, Pavio N, Aggarwal R, Labrique A, Wedemeyer H, et al. Hepatitis E virus infection. Nat Rev Dis Primers. 2017;3:17086.

4. Sridhar S, Chan JFW, Yap DYH, Teng JLL, Huang C, Yip CCY, et al. Genotype 4 hepatitis E virus is a cause of chronic hepatitis in renal transplant recipients in Hong Kong. J Viral Hepat. 2017.

5. Gerolami R, Moal V, Colson P. Chronic hepatitis E with cirrhosis in a kidney-transplant recipient. N Engl J Med. 2008;358(8):859-60.

6. Kamar N, Selves J, Mansuy JM, Ouezzani L, Peron JM, Guitard J, et al. Hepatitis E virus and chronic hepatitis in organ-transplant recipients. N Engl J Med. 2008;358(8):811-7.

7. Tavitian S, Peron JM, Huynh A, Mansuy JM, Ysebaert L, Huguet F, et al. Hepatitis E virus excretion can be prolonged in patients with hematological malignancies. J Clin Virol. 2010;49(2):1414.

8. Ollier L, Tieulie N, Sanderson F, Heudier P, Giordanengo V, Fuzibet JG, et al. Chronic hepatitis after hepatitis $E$ virus infection in a patient with non-Hodgkin lymphoma taking rituximab. Ann Intern Med. 2009;150(6):430-1.

9. Colson P, Kaba M, Moreau J, Brouqui P. Hepatitis E in an HIV-infected patient. J Clin Virol. 2009;45(4):269-71.

10. Dalton HR, Bendall RP, Keane FE, Tedder RS, ljaz S. Persistent carriage of hepatitis E virus in patients with HIV infection. N Engl J Med. 2009;361(10):1025-7.

11. Lhomme S, Marion O, Abravanel F, Chapuy-Regaud S, Kamar N, Izopet J. Hepatitis E Pathogenesis. Viruses. 2016;8(8).

12. European Association for the Study of the Liver. Electronic address eee, European Association for the Study of the L. EASL Clinical Practice Guidelines on hepatitis E virus infection. J Hepatol. 2018.

13. Norder H, Karlsson M, Mellgren A, Konar J, Sandberg E, Lasson A, et al. Diagnostic performance of five assays for anti-HEV IgG and IgM in a large cohort study. J Clin Microbiol. 2015.

14. Pas SD, Streefkerk RH, Pronk M, de Man RA, Beersma MF, Osterhaus AD, et al. Diagnostic performance of selected commercial HEV IgM and IgG ELISAs for immunocompromised and immunocompetent patients. J Clin Virol. 2013;58(4):629-34.

15. Vollmer T, Diekmann J, Eberhardt M, Knabbe C, Dreier J. Monitoring of Anti-Hepatitis E Virus Antibody Seroconversion in Asymptomatically Infected Blood Donors: Systematic Comparison of Nine Commercial Anti-HEV IgM and IgG Assays. Viruses. 2016;8(8).

16. Wenzel JJ, Preiss J, Schemmerer M, Huber B, Jilg W. Test performance characteristics of AntiHEV IgG assays strongly influence hepatitis E seroprevalence estimates. J Infect Dis. 2012;207(3):497500.

17. Drobeniuc J, Meng J, Reuter G, Greene-Montfort T, Khudyakova N, Dimitrova Z, et al. Serologic assays specific to immunoglobulin $M$ antibodies against hepatitis $E$ virus: pangenotypic evaluation of performances. Clin Infect Dis. 2010;51(3):e24-7.

18. Kodani M, Kamili NA, Tejada-Strop A, Poe A, Denniston MM, Drobeniuc J, et al. Variability in the performance characteristics of IgG anti-HEV assays and its impact on reliability of seroprevalence rates of hepatitis E. J Med Virol. 2017;89(6):1055-61.

19. Abravanel F, Sandres-Saune K, Lhomme S, Dubois M, Mansuy JM, Izopet J. Genotype 3 diversity and quantification of hepatitis e virus RNA. J Clin Microbiol. 2012;50(3):897-902.

20. Avellon A, Morago L, Garcia-Galera del Carmen M, Munoz M, Echevarria JM. Comparative sensitivity of commercial tests for hepatitis E genotype 3 virus antibody detection. J Med Virol. 2015;87(11):1934-9. 
21. Hartl J, Otto B, Madden RG, Webb G, Woolson KL, Kriston L, et al. Hepatitis E Seroprevalence in Europe: A Meta-Analysis. Viruses. 2016;8(8).

22. Abravanel F, Chapuy-Regaud S, Lhomme S, Miedouge M, Peron JM, Alric L, et al. Performance of anti-HEV assays for diagnosing acute hepatitis $E$ in immunocompromised patients. J Clin Virol. 2013;58(4):624-8.

23. Abravanel F, Lhomme S, Chapuy-Regaud S, Peron JM, Alric L, Rostaing L, et al. Performance of a new rapid test for detecting anti-hepatitis $E$ virus immunoglobulin $M$ in immunocompetent and immunocompromised patients. J Clin Virol. 2015;70:101-4.

24. Legrand-Abravanel F, Thevenet I, Mansuy JM, Saune K, Vischi F, Peron JM, et al. Good performance of immunoglobulin $\mathrm{M}$ assays in diagnosing genotype 3 hepatitis $\mathrm{E}$ virus infections. Clin Vaccine Immunol. 2009;16(5):772-4.

25. Schnegg A, Burgisser P, Andre C, Kenfak-Foguena A, Canellini G, Moradpour D, et al. An Analysis of the Benefit of Using HEV Genotype 3 Antigens in Detecting Anti-HEV IgG in a European Population. PLoS One. 2013;8(5):e62980.

26. Huang $S$, Zhang $X$, Jiang $H$, Yan $Q$, Ai $X$, Wang $Y$, et al. Profile of acute infectious markers in sporadic hepatitis E. PLoS One. 2010;5(10):e13560.

27. Fogeda $M$, de Ory F, Avellon A, Echevarria JM. Differential diagnosis of hepatitis E virus, cytomegalovirus and Epstein-Barr virus infection in patients with suspected hepatitis E. J Clin Virol. 2009;45(3):259-61.

28. Hyams C, Mabayoje DA, Copping R, Maranao D, Patel M, Labbett W, et al. Serological cross reactivity to $C M V$ and $E B V$ causes problems in the diagnosis of acute hepatitis $E$ virus infection. $J$ Med Virol. 2014;86(3):478-83.

29. Myint KS, Guan M, Chen HY, Lu Y, Anderson D, Howard T, et al. Evaluation of a new rapid immunochromatographic assay for serodiagnosis of acute hepatitis E infection. Am J Trop Med Hyg. 2005;73(5):942-6.

30. Bendall R, Ellis V, ljaz S, Ali R, Dalton H. A comparison of two commercially available anti-HEV IgG kits and a re-evaluation of anti-HEV IgG seroprevalence data in developed countries. J Med Virol. 2010;82(5):799-805.

31. Mansuy JM, Bendall R, Legrand-Abravanel F, Saune K, Miedouge M, Ellis V, et al. Hepatitis E Virus Antibodies in Blood Donors, France. Emerg Infect Dis. 2011;17(12):2309-12.

32. Abravanel F, Goutagny N, Perret C, Lhomme S, Vischi F, Aversenq A, et al. Evaluation of two VIDAS ((R))prototypes for detecting anti-HEV IgG. J Clin Virol. 2017;89:46-50.

33. Zhang J, Li SW, Wu T, Zhao Q, Ng MH, Xia NS. Hepatitis E virus: neutralizing sites, diagnosis, and protective immunity. Rev Med Virol. 2012;22(5):339-49. 


\section{$349 \quad$ Figure legends}

350 Figure 1. Linearity of the VIDAS ${ }^{\circledR}$ ANTI-HEV IgG assay.

351 
Figure 1

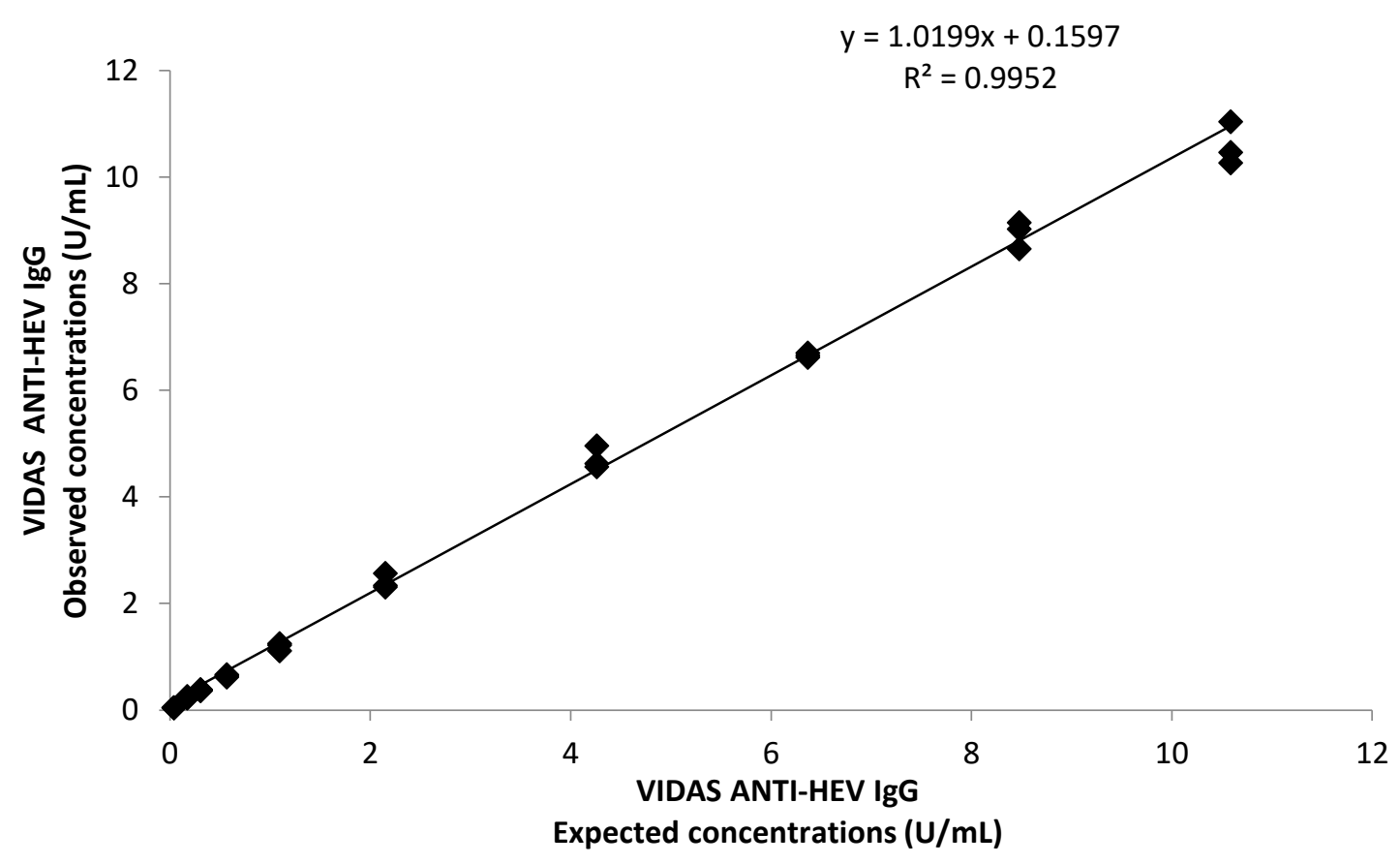


Table 1: Variability of the VIDAS $^{\circledR}$ anti-HEV IgM and IgG assays

\begin{tabular}{|c|c|c|c|c|c|}
\hline \multirow[t]{4}{*}{ Test } & Sample & Mean & Repeatability & Reproducibility & Reproducibility \\
\hline & & value & within-run & Within-lot & Between-lot \\
\hline & & & CV (\%) & Within-instrument & Within-instrument \\
\hline & & & & CV (\%) & CV (\%) \\
\hline \multirow[t]{3}{*}{$\lg M$} & Sample 1 & 0.91 & 9.9 & 12.3 & 13.0 \\
\hline & Sample 2 & 1.60 & 4.1 & 7.0 & 7.4 \\
\hline & Sample 3 & 13.15 & 5.1 & 7.4 & 7.4 \\
\hline \multirow[t]{4}{*}{ IgG } & Sample 1 & 0.14 & 7.8 & 11.9 & 11.9 \\
\hline & Sample 2 & 0.64 & 5.1 & 8.6 & 9.1 \\
\hline & Sample 3 & 2.88 & 4.5 & 7.5 & 10.8 \\
\hline & Sample 4 & 6.97 & 4.6 & 7.8 & 9.7 \\
\hline
\end{tabular}


Table 2: Cross reactivity study for the VIDAS $®$ anti-HEV assays

\begin{tabular}{|c|c|c|c|c|c|c|c|c|}
\hline & \multicolumn{4}{|c|}{ VIDAS® ANTI-HEV IgM } & \multicolumn{4}{|c|}{ VIDAS@ ANTI-HEV IgG } \\
\hline Organism/Condition & $\mathbf{N}$ & Positive & Negative & $\begin{array}{l}\text { \% Cross } \\
\text { Reactivity }\end{array}$ & $\mathrm{N}$ & Positive & Negative & $\begin{array}{l}\% \text { Cross } \\
\text { Reactivity }\end{array}$ \\
\hline Anti-Hepatitis A vírus & 10 & 0 & 10 & $0 \%$ & 10 & 0 & 10 & $0 \%$ \\
\hline Anti-Hepatitis B vírus & 14 & 0 & 14 & $0 \%$ & 10 & 1 & 9 & $10 \%$ \\
\hline Anti-Hepatitis $C$ vírus & 12 & 0 & 12 & $0 \%$ & 10 & 0 & 10 & $0 \%$ \\
\hline Anti-Cytomegalovirus & 13 & 0 & 13 & $0 \%$ & 10 & 0 & 10 & $0 \%$ \\
\hline Anti-Epstein Barr Virus & 10 & 0 & 10 & $0 \%$ & 10 & 0 & 10 & $0 \%$ \\
\hline Anti-Dengue virus & 12 & 0 & 12 & $0 \%$ & 10 & 0 & 10 & $0 \%$ \\
\hline $\begin{array}{c}\text { Anti-Human } \\
\text { Immunodeficiency virus }\end{array}$ & 10 & 1 & 10 & $10 \%$ & 12 & 0 & 12 & $0 \%$ \\
\hline Malaria & 10 & 0 & 10 & $0 \%$ & 26 & 3 & 23 & $11 \%$ \\
\hline
\end{tabular}

